\title{
Diatoms and Their Ecological Importance
}

\section{João Serôdio}

Departament of Biology and CESAM - Centre for Environmental and Marine Studies, University of Aveiro, Campus de Santiago, 3810-193 Aveiro, Portugal

jserodio@ua.pt

\section{Johann Lavaud}

CNRS/Université Laval, UMI3376 Takuvik Joint International Laboratory, Département de Biologie, Pavillon Alexandre Vachon, Université Laval, 1045 avenue de la Médecine, Québec, Qc, G1V 0A6, Canada

Johann.Lavaud@bio.ulaval.ca

\section{Definition}

Diatoms are unicellular or colonial photoautotrophic microalgae, eukaryotic organisms classified as protists of the group of the Bacillariophyta. They are characterized by the unique feature of possessing a cell wall made of silica. Diatoms form an extremely diverse and evolutionarily successful group. They are found in all marine and freshwater habitats and in moist terrestrial habitats, being the most diverse group of algae, the number of species being estimated to reach between 100,000 (Mann and Vanormelingen 2013) and 200,000 (Armbrust 2009). Diatoms have an enormous ecological importance, contributing to $20-25 \%$ of the Earth's global primary production (Field et al. 1998; Sarthou et al. 2005). Their photosynthetic activity accounts for $40 \%$ of the marine primary production, being comparable to the total amount fixed by all the terrestrial rain forest combined (Armbrust 2009). However, their critical role in the functioning and biodiversity of oceanic and coastal zones, while representing a major carbon sink and supporting important marine food webs, is threatened by ongoing climate change, namely by ocean acidification and eutrophication.

Synonyms (optional) 
Introduction. Diatoms are unicellular or colonial photoautotrophic microalgae. Diatom cells vary between a wide range of sizes, from $5 \mu \mathrm{m}$ to above $1 \mathrm{~mm}$ in diameter or length (Sabater 2009). They are most commonly found as single cells, but can form colonies, living in suspension in the water column or attached to substrata. Diatoms are found in all marine and freshwater habitats and in moist terrestrial habitats, covering extreme environments like sea ice (Arrigo 2014) or deep marine sediments well below the photic zone of the ocean (Cahoon et al. 1994). Diatoms are a major constituent of the phytoplankton in oceanic and coastal waters, where they often dominate over other groups of microalgae or cyanobacteria (Armbrust 2009). They are typically the dominant group in the microphytobenthos, the highly productive biofilm-forming communities of microalgae and cyanobacteria that colonize intertidal flats or shallow subtidal sediments (Underwood and Kromkamp 1999). Their ubiquity in virtually all marine habitats (Mock and Medlin 2012) and ability to strive in extreme habitats, such as polar systems (Lyon and Mock 2014) or under prolonged darkness (Frankenbach et al. 2019; Kennedy et al. 2019), is believed to be based on their unique physiological and metabolic features (Wilhelm et al. 2006; Gruber and Kroth 2017).

The siliceous cell wall. The most distinctive feature of diatoms is the presence of a silicified cell wall ('frustule') made of two identical pieces ('valves'), which gave origin to the name of the group (from the greek word 'diatomos', meaning 'cut in half'). The two pieces overlap each other like the parts of a Petri dish, with a larger one ('epitheca') partially enclosing a smaller one ('hypotheca'). Because the valves do not increase in size after being formed, cell division implies the formation of new, smaller valves within the ones of the parental cell, causing a gradual reduction in cell size over several generations (De Tommasi et al. 2017). Original cell size is restored through sexual reproduction, by the production of diploid zygotes called auxospores (Davidovich et al. 2015).

The siliceous cell wall has been thought to be a major factor explaining the adaptive success of diatom, as it confers multiple advantages, such as the following (Pickett-Heaps 2003): i) although rigid and impermeable, it is transparent and porous, allowing light penetration and the diffusion of carbon and nutrients, thus permitting photosynthesis; ii) silica is an abundant element, that is available from sand and suspended silt, and only in oligotrophic waters limits diatom growth; iii) the uptake and precipitation of silica is efficient, being energetically cheaper than and equivalent organic wall.

Diatom cell walls are rich in complex and intricated ornamentation that result from the deposition of siliceous material in regular patterns. Due to its enormous intricacy and diversity, the morphology of the frustule has been the basis for traditional diatom taxonomy and classification since the first microscopy observations (Round et al. 1990). The advent of scanning electron microscopy, revealing with finer detail the ornamentation of the cell wall, 
caused an increase in the number of diatom taxa, as compared to the previously described on the basis of light microscopy observations (Round et al. 1990). However, phenotypical changes in the frustule morphology may occur as responses to varying environmental conditions, affecting their taxonomical value. Recent approaches based on molecular sequence data are contributing to improved phylogenetic-based taxonomical classifications (Sims et al. 2006).

Diversity and evolution. Diatoms are an extremely diverse and evolutionarily successful group. They appeared between 190 and 250 million years ago, depending if the estimates are based on the fossil record or on molecular-clocks (Benoiston et al. 2017). Diatoms are the most diverse group of algae, the number of existent species being estimated to reach above 100,000 (Mann and Vanormelingen 2013) and even up to 200,000 (Armbrust 2009). Diatoms are eukaryotic organisms, classified as protists of the group of the Bacillariophyta. Despite long and intensive research, the phylogeny and classification of the group is still under debate (Yu et al. 2018). Diatoms have evolved through two successive endosymbiotic events from which originate both their secondary plastid (Dorrell and Bowler 2017) and chimeric genome harboring a unique mix of bacterial, algal and animal-like features (Tirichine et al. 2017). The diatom plastid is thought to derive from red algae, originally suggested by the conservation of chlorophyll $c$ and a plastid four membrane-bound ultrastructure, and later supported by plastid gene trees (Dorrell and Bowler 2017).

There are two main groups of diatoms, the centrics and the pennates, which differ markedly regarding key cytological, biological and ecological aspects, that include cell wall symmetry, chloroplast number and morphology, sexual reproduction and motility (PickettHeaps 2003). The most obvious difference between the two groups is cell wall symmetry. Many centric cells show radially symmetrical valves, with radially organized patterns in valve ornamentation (Fig. 1A). Pennate species, while showing a large variety of forms and ornamentation complexity, typically show a well-defined main axis conferring a clearly nonradial symmetry (Fig. 1B). Another major morphological difference regards chloroplasts, with the centrics having a large number of small chloroplasts, and the pennates often possessing one or two large chloroplasts per cell (Fig. 2A, B). Centric diatoms are typically planktonic, often dominating the phytoplankton, especially in turbulent, nutrient-rich marine waters (Malviya et al. 2016). Pennate diatoms are predominantly benthic, dominating the microphytobenthos, the biofilm-forming communities that colonize intertidal and well-lit subtidal sediments (Underwood and Kromkamp 1999), and sea-ice habitats (Poulin et al. 2011).

These differences in habitat preference between centrics and pennates seem to be associated with the evolution of directed motility in the presently larger group of pennate diatoms, the raphid pennates, enabled by the development of the 'raphe', a longitudinal thin 
and long slit through the surface of the valve (Nakov et al. 2018). However, not all pennates possess a raphe, for which reason the pennates are further separated between the araphids (without raphe) and the raphids (with raphe).

Motility in pennate diatoms. The raphe and associated cell motility are relatively recent traits in diatom evolution, having appeared during the Palaeocene, ca. 30 million years ago (Armbrust 2009). Their appearance is hypothesized to have conferred an adaptive advantage to colonize new niches including the sedimentary microenvironment, due to an improved efficiency in fast responding to environmental gradients (light, nutrients) and exploiting habitat heterogeneity (Cohn et al. 2015; Nakov et al. 2018). The evolution of motility is thought to be a primary driver of diatom diversification, explaining the rapid and large expansion of raphid pennate species, which are currently the most numerous group of diatoms (Kooistra et al. 2007).

The most common form of motility in pennate diatoms is known as 'gliding', consisting in directed cell movement, typically along the direction parallel to the longitudinal axis of the cell, and when the cell is in close contact with hard surfaces (Edgar and PickettHeaps 1984). Directed motility, for example towards a stimulus, is achieved by varying the time between the reversal of direction, causing forward progression when the movement in the direction of the stimulus lasts longer than away from it (Cohn et al. 2004; Apoya-Horton et al. 2006). Diatom gliding is a complex process, involving the extrusion of adhesive, mucilaginous extracellular polymeric substances (EPS) through the raphe. According to the widely accepted model proposed by Edgar and Pickett-Heaps (Consalvey et al. 2004; Molino and Wetherbee 2008), diatom gliding is based on an actin-myosin mechanism, resulting in the transient attachment of the cell to the substratum while moving. Actin filaments run the length of the raphe in the cytoplasm immediately adjacent to the cell membrane and allows the cell to attach and to glide over of the substratum (Poulsen et al. 1999).

Ecology. Diatoms have an enormous ecological importance. Through their photosynthetic activity, the group contributes to a massive $20-25 \%$ of the Earth's global primary production, carbon fixation and oxygen release into the atmosphere (Field et al. 1998; Sarthou et al. 2005). The amount of carbon fixed by diatoms' photosynthesis per year represents $40 \%$ of total marine primary production, being equivalent to the total amount fixed by all the terrestrial rain forest combined (Armbrust 2009). Diatom productivity is thus a key source of carbon for marine, coastal and estuarine trophic webs, supporting a range of animal populations, from small crustacean to commercially-valuable fishes, seabirds and marine mammals (Benoiston et al. 2017). Because of the heavy siliceous frustule, planktonic diatoms tend to sink through the water column, carrying organic carbon to the deep zones of the ocean. There, it is used as food for deep-sea organisms, remineralized back to $\mathrm{CO}_{2}$, 
fueling the ocean's carbon pump, or converted to carbonates and incorporated in deep sediments (Tréguer et al. 2018).

The vertical migration of large centric diatoms along the water column represents a form of 'nutrient mining', through which substantial amounts of nutrients are transported upwards across the nutricline, replenishing the otherwise nutrient-depleted photic layer and contributing to new production (Singler and Villareal 2005). Vertical migration also causes that the photosynthetically-fixed carbon near the ocean surface is transported downwards and respired at sub-photic layers. These processes have a large impact on the vertical fluxes of nitrogen (and other nutrients like phosphorous), and have been estimated to contribute to more than one quarter of the ocean surface nitrate pool (Singler and Villareal 2005). The vertical migration of centric diatoms is widespread, and has major biogeochemical consequences, calling for the reassessment of the role of motility in marine phytoplankton and of the predicted implications of global warming on changes in phytoplankton diversity (Villareal et al. 2014).

Diatoms also strongly influence the carbon cycling in benthic sedimentary habitats. Diatom gliding causes the excretion from the raphe of large amounts of carbon-rich mucilage formed by extracellular polymeric substances (EPS) (Pickett-Heaps 2003) which represent a major source of organic carbon fueling the growth of heterotrophic bacteria and their remineralization activity (Bohórquez et al. 2017). A similar high excretion of EPS has been reported for sea-ice diatoms (Underwood et al. 2013). The critical role of diatoms in the global carbon cycle makes them major players, as well as sentinels of environmental disturbances, in the context of global change scenarios (Raven 2017).

Due to their abundance in planktonic and benthic habitats, and to the strict dependence of silicic acid for forming their cell walls, diatoms are main drivers of the silicate cycle at the global scale (Tréguer and De La Rocha 2013). In the ocean, diatoms are a major sink of silica, ultimately causing the accumulation on the sea floor of massive deposits of cell walls from dead cells, called 'diatomaceous earth' or 'diatomite'. On the other hand, the availability of dissolved silicic acid is often a limiting factor of diatom growth, determining the productivity and species composition of phytoplankton communities (Tréguer and De La Rocha 2013). On estuarine tidal flats and subtidal sediments, diatom-dominated microphytobenthic biofilms also strongly affect the fluxes of silica across the sediment-water interface, influencing the silica concentrations in the water column (Ní Longphuirt et al. 2009; Bondoc et al. 2016a; Welsby et al. 2016).

Reasons for success. Several factors seem to contribute to the success of diatoms, including specific subcellular light energy distribution and allocation patterns of carbon into macromolecules (Dorrell and Bowler 2017; Wagner et al. 2017). In comparison with other photoautotrophs, diatoms appear as particularly efficient in coping with high and/or 
fluctuating solar light intensities (Ruban et al. 2004; Wilhelm et al. 2006), which are a major cause of photoinhibition, the light-induced damage to the photosynthetic apparatus, in many situations a main limitation of microalgae productivity (Raven 2011). This ability has been attributed to the efficient operation of energy-dissipation photoprotective processes of diatoms, allowing withstanding the high light levels and rapid fluctuations in light exposure occurring in the turbulent upper layers of the ocean's photic zone (Lavaud and Goss 2014). Diatoms are known to be highly efficient for thermal dissipation of excess absorbed energy (Buck et al. 2019). One of the main mechanisms underlying this capacity for thermal dissipation is the so-called xanthophyll cycle, a biochemical process consisting in the reversible conversion of photosynthetic pigment under high light conditions (Goss and Lepetit 2015). Unlike land plants, in diatoms and other microalgae group, the xanthophyll cycle involves the conversion of the pigment diadinoxanthin into the energy-dissipating form diatoxanthin (Lavaud et al. 2002).

Cell motility also plays a role in enhancing productivity, by allowing cells to actively exploit spatial heterogeneities in the resource distribution. Planktonic centric species can regulate their buoyancy and move vertically in the water column, between the surficial nutrient-poor photic zone and the nutrient-rich deeper layers (Villareal et al. 1999). This capacity to move vertically in the water column has been thought to represent an adaptation to living in stratified waters, typical of warm, oligotrophic regions (Kemp and Villareal 2013). Vertical migration confers these cells the capability for obtaining nutrients from sub-euphotic layers and for photosynthetizing in well-lit conditions, and for avoiding direct competition with much more abundant, non-migratory smaller phytoplankton, overcoming the disadvantages of their larger size (Villareal et al. 2014).

In the benthos, directed vertical migration by pennate diatoms appears to have an even more important significance in terms of exploiting environmental heterogeneity. Directed motility allows benthic diatoms to respond behaviorally to a wide array of abiotic and biotic factors and cues, such as visible light (intensity and spectrum) (Cohn et al. 1999), ultra-violet radiation (Waring et al. 2007), gravity (Frankenbach et al. 2014), temperature (Cohn et al. 2003), salinity (Sauer et al. 2002), desiccation (Coelho et al. 2009), pH (Cohn and Disparti 1994), chemical gradients (Bondoc et al. 2016a), or pheromones (Bondoc et al. 2016b). Responses to intensity and spectral composition of light are amongst the most important for diatoms, as they not only directly determine photosynthetic rates and growth, but also photodamage and possibly cell death (Serôdio et al. 2006). The motility response of pennate diatoms to changes in light intensity is characterized by the avoidance of both darkness and low light and of very high light intensities, and the preference of intermediate irradiance levels (Serôdio et al. 2006). Furthermore, due to the comparable scales of spatial variability of resources like light or nutrients, the diatom cell size and the distances covered 
through gliding, motile diatoms are able to rapidly move towards regions with more favorable light, carbon or nutrient conditions within the sedimentary microhabitat (Cohn et al. 2015; Bondoc et al. 2016a) or to avoid unfavorable conditions such as photoinhibitory irradiances (Serôdio et al. 2006), or predators (Kingston 1999). Vertical movement by raphid diatoms is partially endogenously controlled, exhibiting a self-sustained rhythm synchronized with environmental day-night and tidal cycles (Consalvey et al. 2004). This allows the cells to anticipate environmental periodicity, such as main periodic events including sunrise or sunset, and tidal ebb or flood (Coelho et al. 2011).

Diatoms also have the ability to survive for prolonged periods in continuous darkness, often while buried in anoxic sediments, and to regain photosynthetic activity and carbon fixation upon exposure to favorable surface conditions (Wasmund 1989; Frankenbach et al. 2019). Survival in darkness or while buried has been documented for deep sea sediments (Wasmund 1989; Cahoon et al. 1994) and Antarctic sediments (Wulff et al. 2008). This is enabled by the capacity to live heterotrophically, based on organic energy sources (Lewin 1953; Tuchman et al. 2006),or by the formation of morphological unchanged resting cells (Jewson et al. 2006) or spores (Sugie and Kuma 2008). Facultative heterotrophy of diatoms seems more common among pennate, benthic forms (Lewin and Hellebust, 1970; Rivkin and Putt, 1987), it was shown to also occur in centric diatoms (Kamp et al., 2013; White, 1974). A similar ability to survive the winter polar night prolonged darkness and rapid reactivation of photosynthetic activity has been reported in polar diatoms (Kvernvik et al. 2018; Kennedy et al. 2019).

Applications. Diatoms have been used for a variety of applications. The inert nature and long-lasting durability of the diatom silica wall makes it possible to use the deposits of frustules from dead cells (known as diatomite) for industrial and commercial purposes, or for geological and paleontological analysis of aquatic sediment (Miettinen 2018). More recently, diatoms have been proposed as valuable sources of bioactive compounds (Lopez et al. 2005) as well of lipids and biofuels, due to their high lipid content, as an alternative to plants or green algae (Ramachandra et al. 2009; Hess et al. 2018). The ability to build complex three-dimensional frustules with light-interacting properties has raised considerable interest in the fields of nanotechnology and nanophotonics (Ellegaard et al., 2016; Ragni et al., 2017).

Addressing SDG14. Since its earliest forms, Sustainable Development Goal 14 (Conserve and sustainably use the oceans, seas and marine resources for sustainable development) has identified the minimization of ocean acidification due to climate change and of nutrient pollution and eutrophication as key targets (targets 14.1 and 14.3, respectively). Diatoms display a critical role in the functioning and biodiversity of oceanic and coastal zones. Their photosynthetic activity represents a major carbon sink, and their 
productivity supports important marine food webs around the globe. However, to what extent wthese processes will be impacted by climate change, ocean acidification and eutrophication, or, on the other hand, may contribute to ameliorate the expected negative impacts (e.g. rising atmospheric $\mathrm{CO}_{2}$ ) clearly requires more study. Efforts should thus be directed towards understanding the impacts of ocean acidification and eutrophication, among other processes, on diatom biology and ecology, in line with specifically DSG14 target 14.A (Increase scientific knowledge, develop research capacity and transfer marine technology).

\section{Cross References}

Phytoplankton

Microphytobenthos

Photoinhibition

\section{References}

Apoya-Horton MD, Yin L, Underwood GJC, Gretz MR (2006) Movement modalities and responses to environmental changes of the mudflat diatom Cylindrotheca closterium (Bacillariophyceae). J Phycol 42:379-390. doi: 10.1111/j.1529-8817.2006.00194.x

Armbrust EV (2009) The life of diatoms in the world's oceans. Nature 459:185-192. doi: $10.1038 /$ nature 08057

Arrigo KR (2014) Sea Ice Ecosystems. Ann Rev Mar Sci 6:439-467. doi: 10.1146/annurevmarine-010213-135103

Benoiston A, Ibarbalz FM, Bittner L, et al (2017) The evolution of diatoms and their biogeochemical functions. Philos Trans R Soc B Biol Sci 372:20160397. doi: 10.1098/rstb.2016.0397

Bohórquez J, McGenity TJ, Papaspyrou S, et al (2017) Different types of diatom-derived extracellular polymeric substances drive changes in heterotrophic bacterial communities from intertidal sediments. Front Microbiol 8:245. doi: 10.3389/fmicb.2017.00245

Bondoc KG V, Heuschele J, Gillard J, et al (2016a) Selective silicate-directed motility in diatoms. Nat Commun 7:10540. doi: 10.1038/ncomms10540 
Bondoc KG V, Lembke C, Vyverman W, Pohnert G (2016b) Searching for a mate:

Pheromone-directed movement of the benthic diatom Seminavis robusta. Microb Ecol 72:287-294. doi: 10.1007/s00248-016-0796-7

Buck JM, Sherman J, Bártulos CR, et al (2019) Lhcx proteins provide photoprotection via thermal dissipation of absorbed light in the diatom Phaeodactylum tricornutum. Nat Commun 10:4167. doi: 10.1038/s41467-019-12043-6

Cahoon LB, Laws RA, Thomas CJ (1994) Viable diatoms and chlorophyll a in continental slope sediments off Cape Hatteras, North Carolina. Deep Res Part II 41:767-782. doi: 10.1016/0967-0645(94)90047-7

Coelho H, Vieira S, Serôdio J (2009) Effects of desiccation on the photosynthetic activity of intertidal microphytobenthos biofilms as studied by optical methods. J Exp Mar Bio Ecol 381:98-104. doi: 10.1016/j.jembe.2009.09.013

Coelho H, Vieira S, Serôdio J (2011) Endogenous versus environmental control of vertical migration by intertidal benthic microalgae. Eur J Phycol 46:271-281. doi:

10.1080/09670262.2011.598242

Cohn SA, Bahena M, Davis JT, et al (2004) Characterisation of the diatom photophobic response to high irradiance. Diatom Res 19:167-179. doi:

10.1080/0269249X.2004.9705869

Cohn SA, Disparti NC (1994) Environmental factors influencing diatom cell motility. J Phycol 30:818-828. doi: 10.1111/j.0022-3646.1994.00818.x

Cohn SA, Farrell JF, Munro JD, et al (2003) The effect of temperature and mixed species composition on diatom motility and adhesion. Diatom Res 18:225-243. doi:

10.1080/0269249X.2003.9705589

Cohn SA, Halpin D, Hawley N, et al (2015) Comparative analysis of light-stimulated motility responses in three diatom species. Diatom Res 30:213-225. doi:

10.1080/0269249X.2015.1058295

Cohn SA, Spurck TP, Pickett-Heaps JD (1999) High energy irradiation at the leading tip of moving diatoms causes a rapid change of cell direction. Diatom Res 14:193-206. doi: 10.1080/0269249X.1999.9705466

Consalvey M, Paterson DM, Underwood GJC (2004) The ups and downs of life in a benthic biofilm: Migration of benthic diatoms. Diatom Res 19:181-202. doi:

10.1080/0269249X.2004.9705870 
Davidovich NA, Davidovich OI, Podunai YA, et al (2015) Reproductive properties of diatoms significant for their cultivation and biotechnology. Russ J Plant Physiol 62:153-160. doi: $10.1134 / \mathrm{S} 1021443715330018$

De Tommasi E, Gielis J, Rogato A (2017) Diatom Frustule Morphogenesis and Function: a Multidisciplinary Survey. Mar Genomics 35:1-18. doi: 10.1016/j.margen.2017.07.001

Dorrell RG, Bowler C (2017) Secondary Plastids of Stramenopiles, 1st edn. Elsevier Ltd.

Drum RW, Gordon R (2003) Star Trek replicators and diatom nanotechnology. Trends Biotechnol. 21:325-328

Edgar LA, Pickett-Heaps JD (1984) Diatom locomotion. Prog Phycol Res 3:47-88

Ellegaard M, Lenau T, Lundholm N, et al (2016) The fascinating diatom frustule — can it play a role for attenuation of UV radiation? J Appl Phycol 28:3295-3306. doi: 10.1007/s10811-016-0893-5

Field CB, Behrenfeld MJ, Randerson JT, Falkowski PG (1998) Primary production of the biosphere: Integrating terrestrial and oceanic components. Science (80- ) 281:237-240. doi: 10.1126/science.281.5374.237

Frankenbach S, Azevedo AA, Reis V, et al (2019) Functional resilience of PSII, vertical distribution and ecosystem-level estimates of subsurface microphytobenthos in estuarine tidal flats. Cont Shelf Res 182:46-56. doi: 10.1016/j.csr.2019.05.018

Frankenbach S, Pais C, Martinez M, et al (2014) Evidence for gravitactic behaviour in benthic diatoms. Eur J Phycol 49:429-435. doi: 10.1080/09670262.2014.974218

Goss R, Lepetit B (2015) Biodiversity of NPQ. J Plant Physiol 172:13-32. doi: 10.1016/j.jplph.2014.03.004

Gruber A, Kroth PG (2017) Intracellular metabolic pathway distribution in diatoms and tools for genome-enabled experimental diatom research. Philos Trans R Soc B Biol Sci 372:20160402. doi: $10.1098 /$ rstb.2016.0402

Hess SK, Lepetit B, Kroth PG, Mecking S (2018) Production of chemicals from microalgae lipids - status and perspectives. Eur J Lipid Sci Technol 120:1-26. doi: 10.1002/ejlt.201700152

Jewson DH, Lowry SF, Bowen R (2006) Co-existence and survival of diatoms on sand grains. Eur J Phycol 41:131-146. doi: 10.1080/09670260600652903

Kemp AES, Villareal TA (2013) High diatom production and export in stratified waters - A 
potential negative feedback to global warming. Prog Oceanogr 119:4-23. doi:

10.1016/j.pocean.2013.06.004

Kennedy F, Martin A, Bowman JP, et al (2019) Dark metabolism: a molecular insight into how the Antarctic sea-ice diatom Fragilariopsis cylindrus survives long-term darkness. New Phytol 223:675-691. doi: 10.1111/nph.15843

Kingston MB (1999) Wave effects on the vertical migration of two benthic microalgae: Hantzschia virgata var. intermedia and Euglena proxima. Estuaries 22:81. doi: $10.2307 / 1352929$

Kooistra H, Gersonde R, Medlin L, Mann D (2007) The origin and evolution of the diatoms: their adaptation to a planktonic existence. In: Falkowski PG, Knoll A (eds) Evolution of Primary Producers in the Sea. Elsevier Academic Press, Amsterdam, pp 207-249

Kvernvik AC, Hoppe CJM, Lawrenz E, et al (2018) Fast reactivation of photosynthesis in arctic phytoplankton during the polar night1. J Phycol 54:461-470. doi:

$10.1111 /$ jpy. 12750

Lavaud J, Goss R (2014) Non-Photochemical Quenching and Energy Dissipation in Plants, Algae and Cyanobacteria. Springer Netherlands, Dordrecht

Lavaud J, Rousseau B, Gorkom HJ Van, et al (2002) Influence of the diadinoxanthin pool size on photoprotection in the marine planktonic diatom Phaeodactylum tricornutum. Plant Physiol 129:1398-1406. doi: 10.1104/pp.002014.

Lewin JC (1953) Heterotrophy in diatoms. J Gen Microbiol 9:305-313. doi: 10.1099/00221287-9-2-305

Lopez PJ, Desclés J, Allen AE, Bowler C (2005) Prospects in diatom research. Curr Opin Biotechnol 16:180-186. doi: 10.1016/j.copbio.2005.02.002

Lyon B, Mock T (2014) Polar Microalgae: New Approaches towards Understanding Adaptations to an Extreme and Changing Environment. Biology (Basel) 3:56-80. doi: 10.3390/biology3010056

Malviya S, Scalco E, Audic S, et al (2016) Insights into global diatom distribution and diversity in the world's ocean. Proc Natl Acad Sci 113:E1516-E1525. doi: 10.1073/pnas. 1509523113

Mann DG, Vanormelingen P (2013) An inordinate fondness? the number, distributions, and origins of diatom species. J Eukaryot Microbiol 60:414-420. doi: 10.1111/jeu.12047

Miettinen A (2018) Diatoms in Arctic regions: Potential tools to decipher environmental 
changes. Polar Sci 0-1. doi: 10.1016/j.polar.2018.04.001

Mock T, Medlin LK (2012) Genomics and Genetics of Diatoms. In: Advances in Botanical Research. Academic Press, pp 245-284

Molino PJ, Wetherbee R (2008) The biology of biofouling diatoms and their role in the development of microbial slimes. Biofouling 24:365-379. doi: $10.1080 / 08927010802254583$

Nakov T, Beaulieu JM, Alverson AJ (2018) Accelerated diversification is related to life history and locomotion in a hyperdiverse lineage of microbial eukaryotes (Diatoms, Bacillariophyta). New Phytol 219:462-473. doi: 10.1111/nph.15137

Ní Longphuirt S, Ragueneau O, Chauvaud L, et al (2009) Diurnal heterogeneity in silicic acid fluxes in shallow coastal sites: Causes and implications. Estuar Coast Shelf Sci 82:495-502. doi: 10.1016/j.ecss.2009.02.014

Pickett-Heaps J (2003) Teacher's Guide, Diatoms: Life in Glass Houses. Melb. Cytographics

Poulin M, Daugbjerg N, Gradinger R, et al (2011) The pan-Arctic biodiversity of marine pelagic and sea-ice unicellular eukaryotes: A first-attempt assessment. Mar. Biodivers. 41:13-28

Poulsen NC, Spector I, Spurck TP, et al (1999) Diatom gliding is the result of an actinmyosin motility system. Cell Motil Cytoskeleton 44:23-33. doi: 10.1002/(SICI)10970169(199909)44:1<23::AID-CM2>3.0.CO;2-D

Ragni R, Cicco S, Vona D, et al (2017) Biosilica from diatoms microalgae: Smart materials from bio-medicine to photonics. J Mater Res 32:279-291. doi: 10.1557/jmr.2016.459

Ramachandra T V, Mahapatra DM, Karthick B, Gordon R (2009) Milking diatoms for sustainable energy: Biochemical engineering versus gasoline-secreting diatom solar panels. Ind Eng Chem Res 48:8769-8788. doi: 10.1021/ie900044j

Raven JA (2017) The possible roles of algae in restricting the increase in atmospheric CO2 and global temperature. Eur J Phycol 52:506-522. doi: 10.1080/09670262.2017.1362593

Raven JA (2011) The cost of photoinhibition. Physiol Plant 142:87-104. doi: 10.1111/j.13993054.2011.01465.x

Round FE, Crawford RM, Mann D (1990) The Diatoms - Biology \& Morphology of the genera. Cambridge University Press, Cambridge 
Ruban A, Lavaud J, Rousseau B, et al (2004) The super-excess energy dissipation in diatom algae: Comparative analysis with higher plants. Photosynth Res 82:165-175. doi: 10.1007/s11120-004-1456-1

Sabater S (2009) The diatom cell and its taxonomical entity. Encycl Inl Waters 1:149-156

Sarthou G, Timmermans KR, Blain S, Tréguer P (2005) Growth physiology and fate of diatoms in the ocean: A review. J Sea Res 53:25-42. doi:

10.1016/j.seares.2004.01.007

Sauer J, Wenderoth K, Maier UG, Rhiel E (2002) Effects of salinity, light and time on the vertical migration of diatom assemblages. Diatom Res 17:189-203

Serôdio J, Coelho H, Vieira S, Cruz S (2006) Microphytobenthos vertical migratory photoresponse as characterised by light-response curves of surface biomass. Estuar Coast Shelf Sci 68:547-556. doi: 10.1016/j.ecss.2006.03.005

Sims PA, Mann DG, Medlin LK (2006) Evolution of the diatoms: insights from fossil, biological and molecular data. Phycologia 45:361-402. doi: 10.2216/05-22.1

Singler HR, Villareal TA (2005) Nitrogen inputs into the euphotic zone by vertically migrating Rhizosolenia mats. J Plankton Res 27:545-556. doi: 10.1093/plankt/fbi030

Sugie K, Kuma K (2008) Resting spore formation in the marine diatom Thalassiosira nordenskioeldii under iron- and nitrogen-limited conditions. J Plankton Res 30:12451255. doi: 10.1093/plankt/fbn080

Tirichine L, Rastogi A, Bowler C (2017) Recent progress in diatom genomics and epigenomics. Curr Opin Plant Biol 36:46-55. doi: 10.1016/j.pbi.2017.02.001

Tréguer P, Bowler C, Moriceau B, et al (2018) Influence of diatom diversity on the ocean biological carbon pump. Nat Geosci 11:27-37. doi: 10.1038/s41561-017-0028-x

Tréguer PJ, De La Rocha CL (2013) The World Ocean Silica Cycle. Ann Rev Mar Sci 5:477501. doi: 10.1146/annurev-marine-121211-172346

Tuchman NC, Schollett MA, Rier ST, Geddes P (2006) Differential Heterotrophic Utilization of Organic Compounds by Diatoms and Bacteria under Light and Dark Conditions. Hydrobiologia 561:167-177. doi: 10.1007/s10750-005-1612-4

Underwood GJC, Aslam SN, Michel C, et al (2013) Broad-scale predictability of carbohydrates and exopolymers in Antarctic and Arctic sea ice. Proc Natl Acad Sci U S A 110:15734-15739. doi: 10.1073/pnas.1302870110 
Underwood GJC, Kromkamp J (1999) Primary production by phytoplankton and microphytobenthos in estuaries. Adv Ecol Res 29:93-153

Villareal TA, Pilskaln C, Brzezinski M, et al (1999) Upward transport of oceanic nitrate by migrating diatom mats. Nature 397:423-425. doi: 10.1038/17103

Villareal TA, Pilskaln CH, Montoya JP, Dennett M (2014) Upward nitrate transport by phytoplankton in oceanic waters: balancing nutrient budgets in oligotrophic seas. PeerJ 2:e302. doi: $10.7717 /$ peerj.302

Wagner H, Jakob T, Fanesi A, Wilhelm C (2017) Towards an understanding of the molecular regulation of carbon allocation in diatoms: the interaction of energy and carbon allocation. Philos Trans R Soc Lond B Biol Sci 372:20160410. doi: $10.1098 /$ rstb.2016.0410

Waring J, Baker NR, Underwood GJC (2007) Responses of estuarine intertidal microphytobenthic algal assemblages to enhanced ultraviolet B radiation. Glob Chang Biol 13:1398-1413. doi: 10.1111/j.1365-2486.2007.01378.x

Wasmund N (1989) Micro-autoradiographic determination of the viability of algae inhabiting deep sediment layers. Estuar Coast Shelf Sci 28:651-656. doi: 10.1016/02727714(89)90052-8

Welsby HJ, Hendry KR, Perkins RG (2016) The role of benthic biofilm production in the mediation of silicon cycling in the Severn Estuary, UK. Estuar Coast Shelf Sci 176:124134. doi: 10.1016/j.ecss.2016.04.008

Wilhelm C, Büchel C, Fisahn J, et al (2006) The regulation of carbon and nutrient assimilation in diatoms is significantly different from green algae. Protist 157:91-124. doi: 10.1016/j.protis.2006.02.003

Wulff A, Roleda MY, Zacher K, Wiencke C (2008) Exposure to sudden light burst after prolonged darkness - A case study on benthic diatoms from Antarctica. Diatom Res 23:519-532

Yu M, Ashworth MP, Hajrah NH, et al (2018) Evolution of the Plastid Genomes in Diatoms, 1st edn. Elsevier Ltd. 
Figures

Fig. 1. A, C. Scanning electron micrographs of frustrules of a centric (Thalassiosira angulata; A) and a pennate diatom (Navicula phyllepta; C). B, D. Optical microscopy photographs of a centric (Coscinodiscus granii; B) and a pennate diatom (Nitzchia sigma; D), showing the differences in chloroplast number and size. A, courtesy of James M. Ehrman, Digital Microscopy Facility, Mount Allison University. B, courtesy of NCC - Benoit Tesson, Université de Nantes. D, courtesy of NCC-Pierre Gaudin, Université de Nantes.
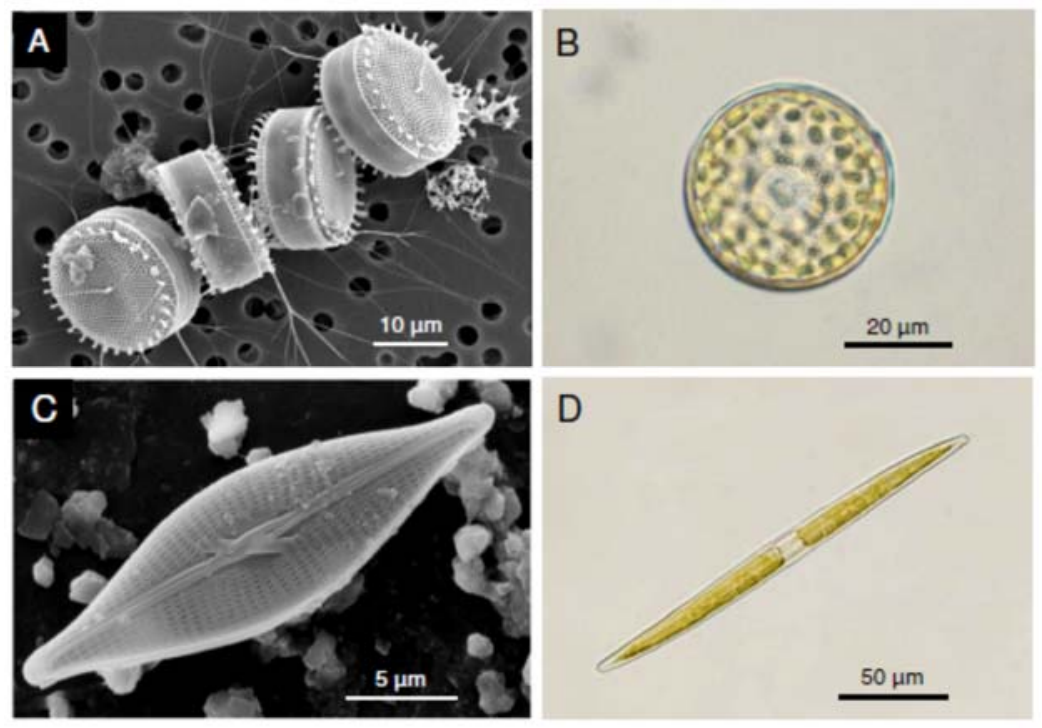